\title{
The Lizard King of SoBe Beverages
}

\section{John Bello}

SoBe

$J$ ohn Bello, aka the "Lizard King," has been lionized in the business press as having been the brilliant entrepreneur who started a beverage company from scratch in early 1995 with his partner, Tom Schwalm, and then sold the product line to PepsiCo seven years later for a reported $\$ 375$ million. What many people do not know is how close Bello came to failing with his SoBe line of innovative drinks.

NEJE: Your great success must make you a very soughtafter speaker in MBA programs across the country.

Bello: It's true. I travel extensively talking to high school, college, and business school students-anyone who will listen-whenever I can about what it takes to be an entrepreneur. I have fun with MBA students, whom I tease. I tell them, "You aren't likely to be entrepreneurs or else you wouldn't be here. You'd be out starting your own businesses and making money for yourselves." That really gets to them. Shakes them up.

NEJE: However, isn't it true, John, that an MBA degree can help entrepreneurs as much as it can those headed for corporate careers?

Bello: Perhaps, but I believe entrepreneurship cannot be taught, and at best, most universities just teach analytics. They don't teach how to overcome the inbred scourge to successful enterprise: Fear of failure. The worry about financial and job security paralyzes a lot of people from pursuing their dreams.

NEJE: What about business skills you can learn in college and then in graduate school?

Bello: Certainly, business school programs impart important skills, such as how to conduct market research or how to analyze a balance sheet, but the really successful entrepreneur needs to have an intimate knowledge and awareness of the product and the market. Passion is the key driver. Do it, move it, make it happen. You can't sit your way to success. You need to talk to the trade and interact with consumers. Salesmanship. That's the stuff you don't get in an MBA program. I have an MBA from Tuck at Dartmouth. Good time, good people, and good analytic education. But, what I learned about process and marketing, I learned at General Foods and in the street. At some point, you have to decide whether you have the intestinal fortitude, perseverance, and smarts to put together a successful venture. With entrepreneurs, it is deeds, not dialogue.

NEJE: Did you know right after grad school you wanted to be an entrepreneur?

Bello: I had a sense from the start that I didn't fit into the corporate mold. Or at least, I knew myself enough to know that I was a better leader than a follower. In the navy as an officer, I did well but it wasn't easy. I had trouble following orders that were "busy work." In Vietnam, that changed. My job was clear and my CO let me do my thing with my team. We were successful doing things almost "by the book." The book, to me, is for nonthinkers. I guess I've always been an iconoclast. Basically, if I am motivated and have an objective I believe in, I'll show up with the goods. The lesson here is have a love and passion for what you do. Most people in this world settle for security and what's in front of them. Circumstances sometime dictate that, but in America, you can be whatever you want to be.

Back to Vietnam, I was put in charge of, among other things, a small "store" on the Mekong Delta that supported PBR's-an Apocalypse Now reality show. At 25, I had control of 60 men and was responsible for the care and feeding of 24 riverboats but the fun job was the base store. With the help of my troops, we turned that tiny shaving cream and cigarette store into a multimillion-dollar operation. We had generals showing up in their helicopters ready to buy television sets, cameras, stereo equipment, and tapes of Iron Butterfly, Steppenwolf, and CCR at great prices. And the profits paid for base welfare and recreation. It was an experience.

NEJE: So from Vietnam you came back to the States and tried your hand at entrepreneurship here?

Bello: No, I ran a navy exchange at Moffett Field, California, and upon leaving the navy, earned an MBA from Tuck. After graduating as an Edward Tuck Scholar, I went into corporate life with General Foods, then 
PepsiCo, and finally the National Football League. I did well because of performance but didn't pay attention to the politics. I wasn't good at that game but I was good at making money for other people. Besides, I found that process was usually an end, and not a means, and that careers were built on both process and politics. That wasn't me.

A lot of people argue about whether entrepreneurs are "made" or "born." I think that people are action-oriented or not. And either you are a risk-taker or rule-maker rather than a "by-the-book" type. Rules in marketing, to me, are guidelines. You simply cannot teach that to people.

I also believe that no matter how good you are, there are many things in a corporate environment that are beyond your control. I tell people in my talks that typically, they will all be fired sooner or later and they better be prepared. I did an outstanding job at NFL Properties, building the company into a $\$ 250$ million business and creating the template as to how sports marketing was done. When the new commissioner came in, he wanted his own team and I was forced out. It was time to leave. Change is good. But you better plan for the eventuality. It happens to virtually everyone.

\section{NEJE: It sounds like you got fired somewhere along the line.}

Bello: Not fired, exactly, but I saw the handwriting on the wall after almost 15 years working in the NFL's Licensing and Properties Division. I knew I had to leave. It was a shock to me; it was 1993 and I was 47 years old but I had run my course at the NFL. I took a year off wondering what to do next when a buddy called me from Arizona Beverages and asked me to join them in restructuring the brand to make it more attractive as a take-over target. I only lasted four, or maybe five, months as a consultant. It was tough because they didn't like my ideas and I firmly believed I could do a better job than they were doing. We really clashed. I came back East thinking that maybe my time with Arizona was well spent because I was intrigued with the opportunities in the beverage industry.

\section{NEJE: The beverage category is so saturated. Why did you think you could make a difference?}

Bello: Call it ego, or maybe it was intuition or stupidity, but I saw how California Coolers had made it big, then Clearly Canadian, and then Arizona Teas. I felt there was still plenty of room left for a more relevant lifestyle brand.

So, in December 1994, I decided to start a beverage company with a partner, Tom Schwalm, who had 24 years of beverage experience and a big checkbook. We sought outside investors but put in plenty of our own money to start the business. It took a year to develop the concept of "South Beach" drinks. No income, no support system. I wanted to introduce a beverage built on lifestyle. That's so important these days. Consumers are advertised to death; they're bored with most of the new products that try to get their attention, and so these products fail. I wanted to develop something special for the marketplace, something that could generate a lot of "buzz" and wordof-mouth advertising, more credible and a lot less costly.

We traveled down to South Beach, Florida, to get a sense of the hot, hip, and trendy lifestyle for which SoBe was known. While there, we saw lots of lizards around the city, including a fresco lizard on the Abbey Hotel that became our new product icon. We thought we were on to something so we decided to call our product "South Beach," and we created a glass bottle design that incorporated a lizard on it.

We had our brand name and we had the packaging. Now we had to develop innovative flavors and a strong product benefit for our consumers. We worked with flavor and bottling companies to see what strategic alliances we could form with them. It wasn't easy. It is a cutthroat business but all is fair in the marketing wars-threats, law suits, intimidation, lack of funding, everything is against you. You have to believe in yourself and persevere. However, there was no way we were going to be pushed around. We eventually found companies who were willing to work with us and launched the brand in December 1995.

\section{NEJE: You were on your way.}

Bello: Or so we thought. Just three months into the venture, by February 1996, we knew we had some significant problems. There were production problems. We were having trouble getting enough distribution and our investors were balking at putting in more money. We had already spent $\$ 2$ million and they weren't about to fork over more cash. Consumers liked some of what we had done, but that wasn't enough to break through.

At that point, some entrepreneurs would have called it quits and given up. Or, some might have insisted they had the right mix and gone off a cliff holding fast to their original concept. I knew we had problems and we had to face reality. Either we'd change our thinking or fail. We started over-mortgaged our homes, shortened the name of the product from "South Beach" to "SoBe," altered the labeling to add two lizards in a "yin and yang" relationship (that was my daughter's suggestion, by the way), and changed the product's formulation.

We walked away from a "me-too" iced tea, to a line of healthy refreshment beverages, capitalizing on an 
emerging interest in energy and health drinks. Health was a cultural shift by the mid-1990s, so instead of just a "fun" drink, we decided to change our positioning and produce a drink that contained herbs and vitamins. Elements such as ginseng, ginkgo biloba, and echinacea that were said to have therapeutic benefits on the mind, body, and spirit were added to our formulation. We thought our audience would quickly recognize the value of drinking a refreshing beverage that was also good for them.

When reevaluating our marketing options, I happened to pick up an issue of Shape magazine that had an article on how yohimbe, arginine, and carnitine could spice up your sex life. This led to our Energy drink that then led to Power, Wisdom, Drive, and Eros. You get the picture. Applying them to our different flavor and herb combinations offered us the marketing opportunity to make a strong product-benefit story.

\section{NEJE: How long did it take for you to recreate your- selves?}

Bello: Nine months. Nine harrowing and very tense months. However by November 1996 we were finally ready to relaunch the brand. We decided on a strong flavor profile, a new graphic look, and a font we took from the movie Braveheart. It just seemed to fit with the image we were trying to create.

We went to the bottlers and produced 25,000 cases of the product. Our distributor hit the market in New Hampshire and the SoBe concept exploded. The product flew off the shelves. I mean, it just blew out everyone's expectations about what the product would do.

We went to the InterBev Trade Show soon after and a Snapple distributor discovered us and offered to help us expand the line. Word was getting around the country that we had a winner and everyone wanted to get in on the action. I knew the more publicity we got, the better we could launch SoBe, so I became the "Lizard King" and worked the public relations angle every chance I could.

We did everything we could think of to create a "buzz" factor. We used a fleet of decorated "Lizard Love Buses" to sample the product and create an image for SoBe that soon everyone was trying to copy. The buzz got louder and louder and the trade listened. We expanded distribution rapidly, spending more money than we had, but "carpe diem." We sampled like everywhere. We, my team including me, went into every retail outlet we could find to talk to the owners and get them to take on our line. If we met resistance, we would give them a couple of free cases, tell them to stock the product in the refrigerated case area, and see what happened. We would not take "no" for an answer. There was always a way to get to "yes" and that's what we needed. Lots of "yeses."

We sought out hip, cool athletes to spread the word about the brand and join "Team Lizard." John Daly, the golfer, and Bode Miller, the ski jumper, were brought on board to help us tell our story. A lot of folks thought we were wrong to turn to John Daly because of some of his past personal problems, but he was really fantastic for us. John was very effective.

\section{NEJE: Smooth sailing from that point on?}

Bello: I only wish. We just couldn't make enough of the product from March to May 1997. I was on the road constantly selling the concept while Tom was trying to hire professional operational and logistics people. It was chaotic. Keeping up with orders was a nightmare.

We were selling health and energy and that combination was a winner. We had a product with no preservatives and no phosphates. We were different. Different with our packaging, different with our formulation, our brand name, heck even our bottle top was different because we put funny sayings on each one; people even started to collect the bottle tops to show their friends.

NEJE: Besides having to catch up with demand, what other problems did you have?

Bello: Legal. We got sued by Arizona Teas in 1997 and 1998 for allegedly infringing on their packaging and bottling design. That distracted us but we eventually won the lawsuits.

\section{NEJE: When did you know you had "arrived?"}

Bello: Easy. Beverage companies started to mimic us. Wannabes. Lots of them. They were coming out with "metoo" products that ripped off our concept.

\section{NEJE: What did you do about it?}

Bello: We kept innovating, being the best, working, and selling. We owned the concept, and in life, if you are not the "lizard," you are the loser. America is a good place for winners. It's a free country and our competition was entitled to try to catch up to us. That's why we had to stay nimble and never take anything for granted. That's the big difference between a large corporation and a start-up like we were. Innovate or die.

We had to stay one step ahead of everyone else. It's really all about leadership. To inspire our sales force, I had to be in the trenches with them. They had to take their inspiration from me. They saw how I never took "no" for an answer. I'd fly off any time, to any place, for any reason that could take our brand further. There were no lim- 
its. Growth, in terms of sales and distribution outlets, was my driving force. We had a lot of sales contests with "Lizard Leaders" winning great awards. We also had our "Lizard Laggards"; those folks either turned things around or they were dropped. Be good or be gone.

I made sure to listen to people everywhere I went. Wholesalers, retailers, our salespeople, customers, you name it. I listened, and I listened hard. I never felt I had all the answers. There were always bright, insightful people along the way who added enormously to our success. You just have to know how to listen.

\section{NEJE: Why sell out to PepsiCo? Why not continue to ride} the wave?

Bello: There were a couple of reasons. First, as an independent beverage company, it's hard to keep growing without the marketing muscle of a large corporation. We had gone as far and as fast as I thought we could go without someone like Pepsi behind us.

Second, we wanted to take our chips off the table. We had worked exhaustively for five, six years, once we reformulated the brand, and we were tired. It was time to rest up some and enjoy being rich.

NEJE: Your busy offices here in Norwalk, Connecticut, suggest you haven't retired.

Bello: No, I ain't done yet. Only now it's a hobby. I am working on a new food line that we are going to call the "Firefighter" brand with colleagues from my NFL and SoBe days. As a social venture, it will benefit Firefighters. Think of chili, snack chips, coffee, and maybe even a
"Firefighter" line of clothing. There's also a beverage line being developed, someone else is working on that as an independent company.

After 9/11, I was inspired by the heroism of New York's firefighters. I've always admired Paul Newman, who has developed some very good consumer products; then his company donates the profits to charity. That's sort of what we're going to do. We're going to donate 25 percent of our net profits to firefighter causes. We've got national, as well as some local, firefighter associations already lined up behind us. The products will be "hazardous material free." No high fructose, transfats, fewer calories, and generally better-for-you fun food. We are working with a firefighter to be one of our chefs.

NEJE: You're only 58 years old so I know you have lots of energy left, but why take on the strain of launching another product nationwide? Why not something less ambitious?

Bello: Because I don't want to say someday I "could have, would have, should have" done this or that. Life is good and it is as good as you want to make it. It's about making a little money and having lots of fun. Any one can do it. Being involved in new product development, working with wonderful people, and seeing my concepts succeed in the marketplace makes me smile. I started off, like so many Americans, in a small town (Plainville, Connecticut). I'm proud of what we did in Vietnam, at the NFL, with SoBe, and I'm ready to follow that up with something exciting, new, and different. 